\title{
Super-resolution Microscopy - Applications in Plant Cell Research
}

\author{
Veit Schubert* \\ Leibniz Institute of Plant Genetics and Crop Plant Research, (IPK) Gatersleben, Seeland, Germany
}

Most of the present knowledge about cell organization and function is based on molecular and genetic methods as well as cytological investigations. While electron microscopy allows identifying cell substructures until a resolution of $\sim 1 \mathrm{~nm}$, the resolution of fluorescence microscopy is restricted to $\sim 200 \mathrm{~nm}$ due to the diffraction limit of light. However, the advantage of this technique is the possibility to identify and co-localize specifically labeled structures and molecules. The recently developed super-resolution microscopy techniques, such as Structured Illumination Microscopy, Photoactivated Localization Microscopy, Stochastic Optical Reconstruction Microscopy, and Stimulated Emission Depletion microscopy allow analyzing structures and molecules beyond the diffraction limit of light. Recently, there is an increasing application of these techniques in cell biology. This review evaluates and summarizes especially the data achieved until now in analyzing the organization and function of plant cells, chromosomes and interphase nuclei using super-resolution techniques.

\section{OPEN ACCESS}

Edited by:

Dan Szymanski,

Purdue University, USA

Reviewed by:

Jozef Samaj,

Palacký University, Czechia

Fang Huang,

Purdue University, USA

${ }^{*}$ Correspondence:

Veit Schubert

schubertv@ipk-gatersleben.de

Specialty section

This article was submitted to

Plant Cell Biology,

a section of the journal

Frontiers in Plant Science

Received: 30 November 2016

Accepted: 24 March 2017

Published: 13 April 2017

Citation:

Schubert V (2017) Super-resolution

Microscopy - Applications in Plant Cell Research. Front. Plant Sci. 8:531. doi: 10.3389/fpls.2017.00531
Keywords: chromosome, nucleus, PALM, plant cell, STED, SIM, STORM, super-resolution

\section{INTRODUCTION}

Light microscopy of DNA and proteins specifically fluorescently labelled by FISH and immunostaining, respectively, as well as live cell imaging based on fluorescent recombinant proteins significantly increased our knowledge concerning cell organization and function, and is an important advantage compared to electron microscopy.

However, due to the diffraction limit of light as defined by Abbe (1873) the spatial resolution of light microscopy including conventional fluorescence techniques is restricted, and reaches only $\sim 200 \mathrm{~nm}$ laterally and $\sim 600 \mathrm{~nm}$ in the axial dimension in biological specimens (Pawley, 1995). Thus, this limited resolution did not allow identifying single molecules and structures with the resolution achieved by electron microscopy.

Recently, to overcome this restriction and to bridge the resolution gap between light and electron microscopy the so-called super-resolution (also referred as optical nanoscopy) techniques SIM, PALM, STORM, and STED offering new insights into molecular structures, interactions and functions were developed. These "subdiffraction" methods can be divided into two different principles: (i) localization of individual fluorophores in the specimen with subdiffraction precision (PALM, STORM), and (ii) structuring the illumination light to collect high spatial frequencies in the image that contain high resolution information (SIM, STED) (Rego et al., 2012).

Abbreviations: CENH3, centromeric histone H3; FISH, fluorescence in situ hybridization; HILO, highly inclined and laminated optical sheet; PALM, Photoactivated Localization Microscopy; RNAPII, RNA polymerase II; SIM, structured illumination microscopy; STORM, stochastic optical reconstruction microscopy; STED, stimulated emission depletion; TIRF, total internal reflection fluorescence. 
To honor the establishment of these stunning methods as PALM/STORM and STED the Nobel Prize in Chemistry 2014 was awarded to Eric Betzig, William Moerner and Stefan Hell, respectively (Gevaux, 2014; Möckl et al., 2014; Stelzer, 2014). The meanwhile widely applied SIM technique has mainly been developed by the late Mats Gustafsson (Gustafsson, 2005; Gustafsson et al., 2008).

In addition to special super-resolution microscope systems established in different research groups, since 2004 also commercial systems are produced by companies as Leica Microsystems (Leica TCS SP8 STED 3X - STED; Leica SR GSD 3D microscope - STORM), Carl Zeiss (Elyra S.1 SIM; Elyra P.1 - PALM; Elyra PS.1 - combination of SIM and PALM), Nikon (N-SIM; N-STORM; combination of N-SIM and N-STORM) and GE Healthcare Life Sciences (DeltaVision OMX System - SIM; DeltaVision Localization Microscopy System - STORM; combination of SIM and STORM).

Excellent reviews describing and comparing the different super-resolution light microscopy methods (Schermelleh et al., 2010; Agrawal et al., 2013; Allen et al., 2014; Komis et al., 2015b; Nienhaus and Nienhaus, 2016) already exist. These techniques were applied successfully in cell biology (Rouquette et al., 2010; Han et al., 2013; Fornasiero and Opazo, 2015) at fixed and live specimens from both pro- and eukaryotes and helped to discover new structures.

Compared to animal tissues and due to varying refractive indices of plant cell organelles inducing spherical aberrations and light scattering, plant cell imaging is particularly challenging (Komis et al., 2015b). Nevertheless, the applications in this field are also increasing. Here I summarize and evaluate the recent achievements in plant cell research applying different superresolution techniques.

\section{APPLICATIONS IN PLANT CELL RESEARCH}

Similar as in other organisms analyzing cell structures of plants is essential to understand biological functions. Thus, increasing efforts are undertaken to apply super-resolution techniques in plant cell research.

Investigations were performed on structures outside and inside of the nucleus, and on condensed chromosomes during cell division (Table 1). Most results were obtained from fixed material, but also live cell imaging based on fluorescently tagged proteins was performed.

Fixed specimens were stained with specific antibodies and/or hybridized with labeled DNA probes. Such experiments were the basis to quantify and colocalize polysaccharides, proteins and DNA.

Live cell imaging has already successfully applied to follow the development of cytoskeleton components, membrane proteins and fungal infection structures.

Meanwhile, in addition to model plants as Arabidopsis and tobacco, also cereals and holocentric wild species were investigated by super-resolution microscopy.
Till now, among the different super-resolution techniques most results were achieved by SIM, whereas fewer applications are based on PALM/STORM and STED (Table 1).

\section{Cellular Components Outside of the Nucleus/Chromosomes}

Super-resolved imaging was applied to investigate interactions between different cells, cellular organelles and nuclei.

In this field Oparka and co-workers studied especially by using SIM cell-cell interactions by plasmodesmata imaging (Bell and Oparka, 2011, 2015) and localized plant virus proteins therein. Additionally, by other groups cytoskeleton components and membrane structures were analyzed on fixed specimens (Table 1). STORM was applied to elucidate the cellulose microfibril organization in onion cells (Liesche et al., 2013) and the cortical microtubule arrangement in Arabidopsis roots (Dong et al., 2015).

Live cell imaging using fluorescent tags such as GFP and mCherry fused to genetically encoded marker proteins together with SIM has been applied to follow the development of microtubules in Arabidopsis hypocotyl epidermal cells (Komis et al., 2014), but also in cotyledon, petiole and root cells (Komis et al., 2015a). Bozkurt et al. (2014) identified by SIM fungus structures after Phytophtora infection in living tobacco leaves. This indicates that SIM is also a very versatile method with a broad application potential in plant live cell research.

Photoactivated Localization Microscopy on living cells was performed to track Arabidopsis root membrane proteins (Hosy et al., 2015) and to localize perinuclear actin in tobacco (Durst et al., 2014).

To date only one STED application in plant cell research has been published. Kleine-Vehn et al. (2011) detected polarcompetent YFP-labeled PIN protein clusters responsible for auxin transport in the apical plasma membrane of living A. thaliana root cells. The high laser power required for STED causing fast bleaching impedes the acquiring of image stacks and longer live cell imaging. In addition, the number of applicable florescence dyes is restricted. The high degree of autofluorescence and the presence of color pigments (e.g., chlorophyll) make plant tissues especially challenging for STED. Obviously, this causes its so far restricted application in plant cell research.

\section{Chromatin and Protein Organization in Interphase Nuclei}

To understand such basic cellular functions as transcription, replication, and DNA repair the organization of chromatin, DNA-DNA, DNA-protein and protein-protein interactions have to be investigated in interphase nuclei. For this aim, superresolution imaging was performed on nuclei in tissue squash preparations. However, especially the imaging of isolated and flow-sorted nuclei delivered excellent resolutions due to the absence of cytoplasm (Table $\mathbf{1}$ ).

FISH with differently labeled DNA probes allowed investigating the subchromosomal arrangement of chromatin within cell nuclei (Schubert et al., 2013) (Figure 1). Compared to widefield microscopy and deconvolution imaging the increased 
TABLE 1 | Applications of super-resolution methods to analyze plant cell structures.

\begin{tabular}{|c|c|c|c|c|}
\hline $\begin{array}{l}\text { Structures/cell stages } \\
\text { analyzed }\end{array}$ & Results & Species $^{a}$ & Methods & Reference \\
\hline \multicolumn{5}{|c|}{ Cellular components outside of the nucleus/chromosomes } \\
\hline Pollen & Analysis of pollen surface texture and shape & 2 & SIM & Sivaguru et al., 2012 \\
\hline Cellulose microfibrils & $\begin{array}{l}\text { Analysis of the cellulose microfibril architecture in the cell } \\
\text { walls of onion-bulb scale epidermal cells }\end{array}$ & 3 & STORM & Liesche et al., 2013 \\
\hline Cortical microtubules & $\begin{array}{l}\text { Organization and development of cortical microtubules in } \\
\text { living hypocotyl epidermal cells }\end{array}$ & 4 & SIM & Komis et al., 2014 \\
\hline Cortical microtubules & $\begin{array}{l}\text { Vizualization of cortical microtubules in living cotyledon, } \\
\text { petiole and root cells }\end{array}$ & 4 & SIM & Komis et al., 2015a \\
\hline Cortical microtubules & $\begin{array}{l}\text { Organization and quantitation of cortical microtubules in } \\
\text { different root cells }\end{array}$ & 4 & STORM & Dong et al., 2015 \\
\hline Endosomes & $\begin{array}{l}\text { Imaging and quantification of early and late endosomes } \\
\text { during root hair formation }\end{array}$ & 4 & SIM & von Wangenheim et al., 2016 \\
\hline Plasmodesmata & Organization of plasmodesmata in leaf parenchyma cells & 11 & SIM & Fitzgibbon et al., 2010 \\
\hline Plasmodesmata & Arrangement of plasmodesmata and callose in leaf cells & 4 & SIM & Bell and Oparka, 2011 \\
\hline Plasma membrane & $\begin{array}{l}\text { Tracking of individual membrane protein motions in living } \\
\text { root epidermal cells }\end{array}$ & 4 & PALM & Hosy et al., 2015 \\
\hline Plasma membrane & $\begin{array}{l}\text { Detection of polar-competent PIN protein clusters } \\
\text { responsible for auxin transport in the apical plasma } \\
\text { membrane of living root cells }\end{array}$ & 4 & STED & Kleine-Vehn et al., 2011 \\
\hline Perinuclear cell region & Localization of perinuclear actin in living tobacco cells (BY-2) & 11 & PALM & Durst et al., 2014 \\
\hline $\begin{array}{l}\text { Plasmodesmata and virus } \\
\text { proteins }\end{array}$ & $\begin{array}{l}\text { Identification of callose and viral movement proteins in the } \\
\text { central cavities of complex plasmodesmata in leaf } \\
\text { epidermal cells }\end{array}$ & 4 & SIM & Fitzgibbon et al., 2013 \\
\hline $\begin{array}{l}\text { Plasmodesmata and virus } \\
\text { proteins }\end{array}$ & $\begin{array}{l}\text { Localization of plant virus movement proteins in } \\
\text { plasmodesmata }\end{array}$ & 10 & SIM & Tilsner et al., 2013 \\
\hline $\begin{array}{l}\text { Sieve element reticulum and } \\
\text { virus proteins }\end{array}$ & $\begin{array}{l}\text { Arrangement of the sieve element reticulum, callose, and } \\
\text { cellulose, and identification of potato virus X filaments in } \\
\text { phloem cells }\end{array}$ & 10,11 & SIM & Bell et al., 2013 \\
\hline $\begin{array}{l}\text { Membrane structures and virus } \\
\text { filaments }\end{array}$ & $\begin{array}{l}\text { Visualization of membrane structures of pseudoviral } \\
\text { replication complexes and individual potato virus X } \\
\text { filaments in leaf cells }\end{array}$ & 10 & SIM & Linnik et al., 2013 \\
\hline $\begin{array}{l}\text { Plasmodesmata and virus } \\
\text { proteins }\end{array}$ & $\begin{array}{l}\text { Localization of RTNLB proteins in the the central } \\
\text { desmotubule of plasmodesmata and their colocalization } \\
\text { with tobacco mosaic virus movement proteins }\end{array}$ & 4 & SIM & Knox et al., 2015 \\
\hline $\begin{array}{l}\text { Membrane domains and } \\
\text { fungus structures }\end{array}$ & $\begin{array}{l}\text { Identification of extrahaustorial membrane domains and } \\
\text { proteins in living leaf cells after Phytophtora infestans } \\
\text { infection }\end{array}$ & 10 & SIM & Bozkurt et al., 2014 \\
\hline \multicolumn{5}{|c|}{ Chromatin and protein organization in interphase nuclei } \\
\hline Somatic interphase & Chromatin ring formation of satellite DNA & 14 & SIM & Ribeiro et al., 2017 \\
\hline Interphase nuclei, mitosis & $\begin{array}{l}\text { Distribution of histone } \mathrm{H} 3 \mathrm{~K} 4 \mathrm{me} 2, \mathrm{H} 3 \mathrm{~K} 9 \mathrm{me} 2 \text { and } \\
\mathrm{H} 3 \mathrm{~K} 27 \mathrm{me} 3 \text { in holocentric chromosomes }\end{array}$ & 9 & SIM & Heckmann et al., 2013 \\
\hline Interphase nuclei & $\begin{array}{l}\text { Detection of active and inactive RNAPII in the proximity of B } \\
\text { chromosome chromatin }\end{array}$ & 17 & SIM & Ma et al., 2017 \\
\hline Meristematic nuclei & $\begin{array}{l}\text { Determination of the spatio-temporal distribution of rDNA } \\
\text { during replication }\end{array}$ & 4 & SIM & Dvořáčková et al., in press \\
\hline $\begin{array}{l}\text { Meristematic and } \\
\text { endopolyploid nuclei }\end{array}$ & $\begin{array}{l}\text { Distribution and quantification of active and inactive RNAPII } \\
\text { within euchromatin }\end{array}$ & 4,17 & SIM & Schubert, 2014 \\
\hline Endopolyploid nuclei & $\begin{array}{l}\text { Distribution and quantification of active and inactive RNAPII } \\
\text { within euchromatin }\end{array}$ & 4 & SIM, PALM & Schubert and Weisshart, 2015 \\
\hline Interphase nuclei & $\begin{array}{l}\text { Co-localization of the transcript elongation factor SPT5 and } \\
\text { RNAPII within euchromatin }\end{array}$ & 4 & SIM & Dürr et al., 2014 \\
\hline Interphase nuclei & $\begin{array}{l}\text { Co-localization between the transcript elongation factors } \\
\text { SPT6L, ELF7 and RNAPII }\end{array}$ & 4 & SIM & Antosz et al., 2017 \\
\hline Differentiated nuclei & $\begin{array}{l}\text { Distribution of SMC3 and CAP-D3; eu- and } \\
\text { heterochromatin characterization in endopolyploid nuclei }\end{array}$ & 4 & SIM & Schubert et al., 2013 \\
\hline
\end{tabular}


TABLE 1 | Continued

\begin{tabular}{|c|c|c|c|c|}
\hline $\begin{array}{l}\text { Structures/cell stages } \\
\text { analyzed }\end{array}$ & Results & Species $^{a}$ & Methods & Reference \\
\hline \multicolumn{5}{|c|}{ Chromatin/protein organization along condensed chromosomes } \\
\hline Pachytene & $\begin{array}{l}\text { Mitochondrial and plastidal DNA localization in B } \\
\text { chromosomes }\end{array}$ & 17 & SIM & Klemme, 2013 \\
\hline Somatic metaphase & $\begin{array}{l}\text { Accumulation of chloroplast- and mitochondria-derived } \\
\text { sequences in B chromosomes }\end{array}$ & 1 & SIM & Ruban et al., 2014 \\
\hline Somatic metaphase & $\begin{array}{l}\text { Localization of satellite repeats along holocentric } \\
\text { chromosomes }\end{array}$ & $13,14,15,16$ & SIM & Ribeiro et al., 2017 \\
\hline Pachytene & $\begin{array}{l}\text { Evaluation of the cytosine methylation status of satellite } \\
\text { DNAs }\end{array}$ & 5 & SIM & Zakrzewski et al., 2014 \\
\hline Somatic metaphase & Detection of sister chromatid exchanges & 7 & SIM & Vu et al., 2014 \\
\hline Somatic metaphase & $\begin{array}{l}\text { Sister chromatid exchange arrangement in mono- and } \\
\text { holocentric chromosomes }\end{array}$ & 9,17 & SIM & Schubert et al., 2016b \\
\hline Somatic metaphase & $\begin{array}{l}\text { Localization of H2AThr120ph and H3S10ph at } \\
\text { chromosome arms }\end{array}$ & 6 & SIM & Sousa et al., 2016 \\
\hline Meiosis & $\begin{array}{l}\text { Analysis of the synaptonemal complex formation and the } \\
\text { progression of meiotic chromosome synapsis }\end{array}$ & 7 & SIM & Phillips et al., 2012 \\
\hline Meiosis & $\begin{array}{l}\text { Analysis of the synaptonemal complex organization and } \\
\text { interlock formation }\end{array}$ & 19 & SIM & Wang et al., 2009 \\
\hline Zygotene & $\begin{array}{l}\text { Colocalization of AFD1 and ASY1 during the synaptonemal } \\
\text { complex formation }\end{array}$ & 19 & SIM & Gustafsson et al., 2008 \\
\hline Mitosis & $\begin{array}{l}\text { Visualization of } 3 \times \mathrm{HMG}-\mathrm{box} \text { proteins at somatic } \\
\text { chromosomes }\end{array}$ & 4 & SIM & Antosch et al., 2015 \\
\hline \multicolumn{5}{|l|}{ Centromeres } \\
\hline Somatic metaphase & $\begin{array}{l}\text { Deviating centromere chromatin organization in A and B } \\
\text { chromosomes }\end{array}$ & 17 & SIM & Banaei-Moghaddam et al., 2012 \\
\hline Metaphase I & $\begin{array}{l}\text { Detection of } \mathrm{CENH} 3 \text { at the centromeres of bi- and } \\
\text { univalents }\end{array}$ & 17 & SIM & Cuacos, 2013 \\
\hline $\begin{array}{l}\text { Interphase nuclei, mitosis, } \\
\text { meiosis }\end{array}$ & Chromatin ring formation at centromeres & $1,4,7,17,18$ & SIM & Schubert et al., 2016a \\
\hline Interphase nuclei, mitosis & $\begin{array}{l}\text { Co-localization of } \mathrm{CENH} 3 \text { and centromere-specific repeats } \\
\text { in holocentromeres }\end{array}$ & 15 & SIM & Marques et al., 2015 \\
\hline $\begin{array}{l}\text { Interphase nuclei, mitosis, } \\
\text { meiosis }\end{array}$ & $\begin{array}{l}\text { Co-localization of tubulin, CENH3, CENP-C and } \\
\text { centromere-specific repeats in holocentromeres }\end{array}$ & 15 & SIM & Marques et al., 2016 \\
\hline Somatic inter- and metaphase & $\begin{array}{l}\text { Localization of } \mathrm{CENH} 3 \text { and centromeric repeats along } \\
\text { holocentric chromosomes }\end{array}$ & $13,14,15,16$ & SIM & Ribeiro et al., 2017 \\
\hline $\begin{array}{l}\text { Interphase nuclei, mitosis, } \\
\text { meiosis }\end{array}$ & $\begin{array}{l}\text { CENH3 amount measurements based on fluorescence } \\
\text { intensities }\end{array}$ & 17 & SIM & Schubert et al., 2014 \\
\hline Somatic metaphase & Localization of CENH3 along holocentric chromosomes & 15 & SIM & Cabral et al., 2014 \\
\hline Mitosis, meiosis & Co-localization of the two CENH3 variants & 7 & SIM & Karimi-Ashtiyani et al., 2015 \\
\hline Somatic inter- and metaphase & Intermingled co-localizaton of $\alpha \mathrm{CENH} 3$ and $\beta \mathrm{CENH} 3$ & 7 & SIM & Ishii et al., 2015 \\
\hline Interphase nuclei & $\begin{array}{l}\text { Intermingled colocalization of } A \text {. thaliana and Zea mays } \\
\text { CENH3s }\end{array}$ & 4 & SIM & Maheshwari et al., 2016 \\
\hline Somatic metaphase & Intermingled co-localizaton of $\alpha \mathrm{CENH} 3$ and H2AThr120ph & 7 & SIM & Demidov et al., 2014 \\
\hline Somatic metaphase & $\begin{array}{l}\text { Localization of CENH3 and H2AThr120ph in holokinetic } \\
\text { chromosomes }\end{array}$ & 9 & SIM & Jankowska et al., 2015 \\
\hline Mitosis & $\begin{array}{l}\text { Co-localization of } \alpha \text { and } \beta \mathrm{CENH} 3, \mathrm{H} 2 \mathrm{ATh} \text {-120ph and } \\
\text { tubulin at holo- and monocentromeres }\end{array}$ & 9,7 & SIM & Wanner et al., 2015 \\
\hline Meiosis & $\begin{array}{l}\text { Co-localization of CENH3, H2AThr120ph and tubulin at } \\
\text { holocentromeres }\end{array}$ & 9 & SIM & Heckmann et al., 2014 \\
\hline Somatic metaphase & $\begin{array}{l}\text { Co-localization of } \mathrm{CENH} 3 \text { and } \alpha \text {-kleisin in mono- and } \\
\text { holocentromeres }\end{array}$ & 9,7 & SIM & Ma et al., 2016 \\
\hline Meristematic nuclei & Co-localization of CENH3 and KNL2 & 4 & SIM & Lermontova et al., 2013 \\
\hline Root tip nuclei & Co-localization of CENH3 and KNL2 & 4 & SIM & Sandmann et al., 2017 \\
\hline Interphase nuclei, mitosis & Co-localization of CENH3 and GIPs at centromeres & 4 & SIM & Batzenschlager et al., 2015 \\
\hline Somatic metaphase & $\begin{array}{l}\text { Co-localization of both CENH3 variants, H2AThr120ph and } \\
\text { H3S28ph in polycentric chromosomes }\end{array}$ & 8,12 & SIM & Neumann et al., 2016 \\
\hline Somatic metaphase & Localization of H2AThr120ph and H3S10ph at centromeres & 6 & SIM & Sousa et al., 2016 \\
\hline
\end{tabular}




\section{TABLE 1 | Continued}

\begin{tabular}{|c|c|c|c|c|}
\hline $\begin{array}{l}\text { Structures/cell stages } \\
\text { analyzed }\end{array}$ & Results & Species $^{a}$ & Methods & Reference \\
\hline \multicolumn{5}{|l|}{ (Sub)telomeres } \\
\hline Somatic metaphase & $\begin{array}{l}\text { Localization of telomeric repeats in holokinetic } \\
\text { chromosomes }\end{array}$ & 9 & SIM & Jankowska et al., 2015 \\
\hline $\begin{array}{l}\text { Interphase nuclei, mitosis, } \\
\text { meiosis }\end{array}$ & Chromatin ring formation at subtelomeres & $1,4,7,17,18$ & SIM & Schubert et al., 2016a \\
\hline
\end{tabular}

a(1) Aegilops speltoides (Boiss.) Chennav.; (2) Agropyron repens (L.) P. Beauv.; (3) Allium cepa L.; (4) Arabidopsis thaliana (L.) Heynh.; (5) Beta vulgaris L.; (6) Coccinia grandis (L.) Voigt; (7) Hordeum vulgare L.; (8) Lathyrus sativus L.; (9) Luzula elegans Lowe; (10) Nicotiana benthamiana Domin; (11) Nicotiana tabacum L.; (12) Pisum sativum L.; (13) Rhynchospora ciliata (G. Mey.) Kük.; (14) Rhynchospora globosa (Kunth) Roem. \& Schult.; (15) Rhynchospora pubera (Vahl) Boeckeler; (16) Rhynchospora tenuis Link; (17) Secale cereale L.; (18) Triticum aestivum L.; (19) Zea mays L.

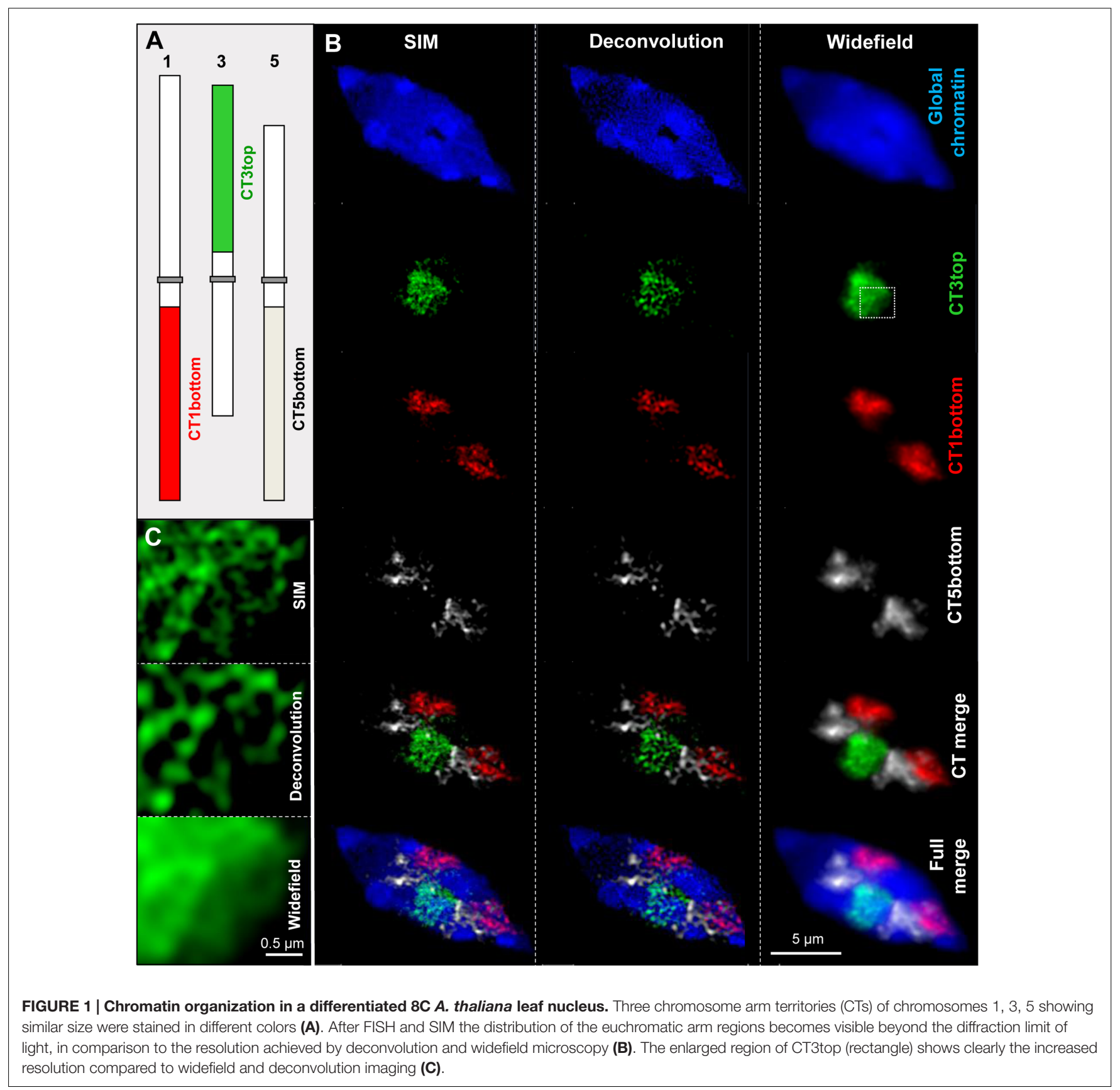


content of information due to the higher resolution obtained by SIM becomes obvious.

Several publications show the distribution and colocalization of RNA polymerase II (RNAPII) enzymes and interacting factors in Arabidopsis nuclei after labeling with specific antibodies. In addition, the relative and absolute quantification of these molecules in 3D image stacks was performed by SIM and PALM, respectively (Schubert, 2014; Schubert and Weisshart, 2015). Figure 2 demonstrates the colocalization of RNAPII and the structural condensin subunit CAP-D3 within the euchromatin of an isolated 32C Arabidopsis nucleus, and the improved resolution achieved by SIM compared to widefield microscopy.

The combination of SIM and PALM feasible with systems such as the Elyra PS.1 from Zeiss enables acquiring image stacks by both techniques subsequently. Then, the combination of these stacks allows counting and localizing single molecules within the structures identified by SIM (Schubert and Weisshart, 2015; Weisshart et al., 2016) (Figure 3).

\section{Chromatin and Protein Organization Along Condensed Chromosomes}

All organisms perform cell divisions, at which for proper segregation during mitosis and meiosis chromosomes have to be condensed. To better understand this process super-resolution microscopy has been used to analyze the distribution and organization of DNA in cereal supernumerary B chromosomes (Ruban et al., 2014), and of satellite DNA along holocentric chromosomes (Ribeiro et al., 2017) (Table 1).

Additionally, the distribution of specific DNA (Zakrzewski et al., 2014) and histone modifications (Sousa et al., 2016) was investigated along condensed chromosomes.

The arrangement of sister chromatids in holocentric chromosomes could be clarified by differential labeling via base analog incorporation during replication followed by SIM (Schubert et al., 2016b).

SIM was also helpful to analyze the synaptonemal complex formation during homologous chromosome paring in prophase I of maize (Gustafsson et al., 2008; Wang et al., 2009) and barley (Phillips et al., 2012).

\section{Centromeres and (Sub)Telomeres}

Centromeres/kinetochores as spindle fiber attachment sites are required for proper chromosome segregation during cell division. Telomeres protect chromosome termini from degradation and fusion. Thus, both are essential to maintain genome stability of organisms.

SIM investigations were helpful to get new insight into the centromere organization during the cell cycle via specifically labeling and co-localizing centromere components such as centromere-specific DNA repeats, kinetochore proteins and histone modifications at centromeric chromatin (Table 1).

Especially the finding that phosphorylated histone $\mathrm{H} 2 \mathrm{~A}$ positive chromatin and different CENH3 variant containing chromatin clusters intermingle to form centromeres has been attained (Demidov et al., 2014; Ishii et al., 2015; Karimi-Ashtiyani et al., 2015), an observation not achievable by refractionlimited widefield resolution. Similar comparative investigations in mono-, poly-, and holocentric plants species provided also new insights into the evolution of centromeres (Wanner et al., 2015; Neumann et al., 2016).

Regarding telomere investigations until now only two publications appeared. One was published about the localization of telomeric repeats in holokinetic Luzula chromosomes (Jankowska et al., 2015), a second about chromatin ring formation at subtelomeres in barley (Schubert et al., 2016a).

\section{SPECIMEN PREPARATION AND THE SUPER-RESOLUTION METHODS}

All super-resolution techniques are based on imaging fluorescent molecules. Consequently, they are used to label structures and molecules of interest. After fixation of a specimen, which should alter the native structures as less as possible, specific fluorescent affinity probes of preferably small size (FAB fragments of antibodies, nanobodies, snap-tags) may be used for labeling (Fornasiero and Opazo, 2015).

The advantage of genetically encoded and expressed fluorescent proteins (Hedde and Nienhaus, 2014) is that they allow investigating dynamic processes in living cells without fixation artifacts. However, due to phototoxicity live cell nanoscopy is much more challenging than imaging fixed specimens (Fornasiero and Opazo, 2015). Hence, fewer live cell imaging results have been published so far in plant cell research (Table 1).

Both structured illumination and localization microscopy may be used for fixed material but also for imaging living cells. Depending on the different super-resolution techniques and the imaging tasks to be performed (e.g., quantification and colocalization of molecules) the specimen preparations have to be adapted accordingly. Staudt et al. (2007) developed a new embedding medium especially useful for STED microscopy to avoid spherical aberrations induced by the refractive index mismatch between the immersion system and the embedding medium of the sample.

\section{Imaging of Fixed Specimens}

The major advantage of SIM is that most preparation and labeling protocols and fluorophores used for widefield fluorescence microscopy are applicable without modification, thus allowing high-throughput experiments. Despite a reliable tissue fixation, the use of high-quality glass slides and especially coverslips (e.g., Marienfeld high precision cover glasses) are important to reach the possible resolution of up to $\sim 120 \mathrm{~nm}$ by a $488 \mathrm{~nm}$ excitation. It is quite important to notice that during SIM raw data acquisition an overexposure must be avoided perfectly. Otherwise, artificial not existing structures and shapes can be generated during the SIM calculation.

Using a Zeiss ELYRA PS.1 microscope system the acquiring of image stacks of up to 30 slices at a distance of $\sim 100 \mathrm{~nm}$ at full resolution $(\sim 1024 \times 1024$ pixel, $80 \mu \mathrm{m} \times 80 \mu \mathrm{m}$ FOV, $100 \mathrm{~ms}$ exposure time), which takes $\sim 4-5 \mathrm{~min}$ in a sequential 

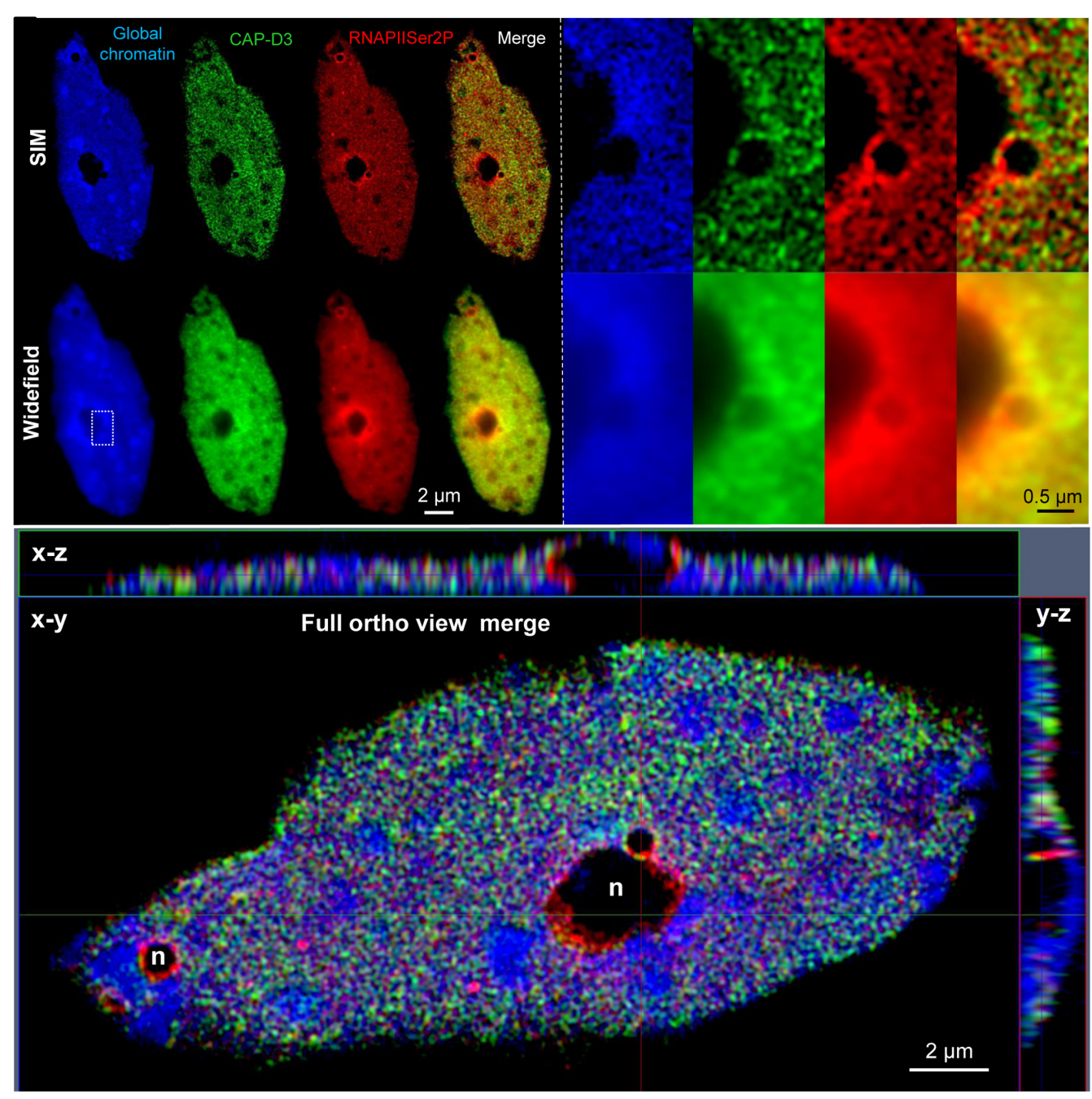

FIGURE 2 | Distribution and co-localization of active RNAPII (phosphorylated at serine 2) and the condensin subunit CAP-D3 in a flow-sorted differentiated 32C A. thaliana leaf nucleus. After immunostaining with specific antibodies and SIM it becomes visible that both proteins are present within euchromatin, but absent from heterochromatin (dense blue staining) and nucleoli ( $\mathrm{n}$ ) (upper left). Especially the enlarged region (rectangle) shows the increased resolution obtained by SIM compared to widefield microscopy (upper right). The ortho view (below) generated from fully merged SIM image stacks visualizes the nucleus as front $(x-y)$ and side $(x-z, y-z)$ views. Relative voxel intensity measurements based on the SIM image stack using the Imaris 8.0 (Bitplane) software showed that this nucleus contains $\sim 19 \%$ less RNAPII than CAP-D3 molecules, and that $\sim 81 \%$ of these molecules colocalize.

3-color experiment (see Figure 1) are the basis to calculate 3D-SIM image stacks within $\sim 10-20 \mathrm{~min}$ (Weisshart et al., 2016). These stacks may be used for 3D-movie rendering by, e.g., the commercial ZEN (Zeiss) (e.g., Schubert et al., 2013, 2016a) or Imaris (Bitplane) (Neumann et al., 2016; Schubert et al., 2016b) softwares.

To reveal the spatial ultrastructure of cellular components SIM delivers best results after applying FISH and/or immunolabelling at relatively flat (up to $\sim 10 \mu \mathrm{m}$ ) tissue squashes and spreadings. But especially useful are isolated and flow-sorted cell nuclei free of disturbing cytoplasm (Dürr et al., 2014; Weisshart et al., 2016; Antosz et al., 2017) (Figure 2).

SIM image stacks are also useful to determine relative molecule amounts via pixel intensity measurements in organelles like nuclei, and to measure the degree of colocalization of differently labeled molecules (Dürr et al., 2014; Schubert, 2014; Antosz et al., 2017) (Figure 2).

Bell and Oparka (2015) developed preparative methods especially for imaging plasmodesmata by SIM on fixed plant tissues.

Practically localization microscopy (PALM, STORM) reaches a circa five-fold higher resolution than SIM. Thus, single molecules may be identified, counted and colocalized in single- and even two-color experiments using, e.g., the fluorescence dyes Alexa488 and Cy5 (Schubert and Weisshart, 2015; Weisshart et al., 2016). However, compared to SIM specimen preparation is more challenging and raw data acquisition and calculations are more time-consuming. To achieve reliable results a high labeling density and efficient 

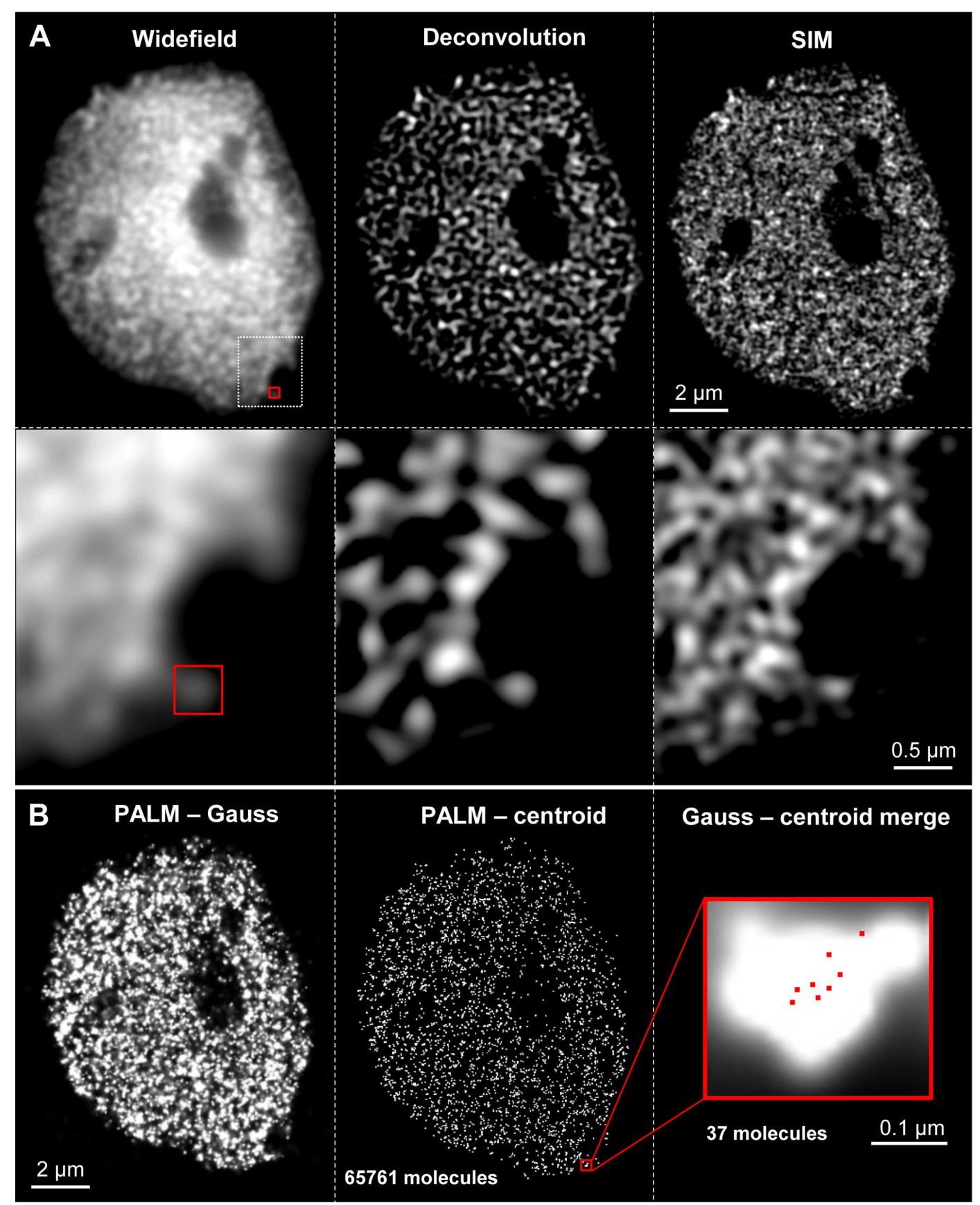

FIGURE 3 | Distribution and quantification of active RNAPII (phosphorylated at serine 2) molecules in a differentiated 16C A. thaliana leaf nucleus. After immunostaining with specific antibodies SIM (A) and PALM (B) were performed consecutively. (A) Compared to widefield and deconvolution microscopy SIM clearly delivers an increased resolution especially visible in the enlarged region (white rectangle) below. This indicates that RNAPII is distributed network-like within the nucleus. (B) After 3D-PALM the resolution becomes further increased when visualized as Gauss distribution (left). Centroid visualization allows the exact localization and counting of single molecules (center). The nucleus with a z extension of $1.2 \mu \mathrm{m}$ contains in total 65761 molecules which were counted in 30 slices of $40 \mathrm{~nm}$. The merged Gauss-centroid view (right) represents the localization of eight single molecules in a single slice of a RNAPII cluster (red rectangle) containing in total 37 molecules in five slices with a total $z$ range of $0.2 \mu \mathrm{m}$.

photoactivation are required (Fernández-Suárez and Ting, 2008).

2D-PALM may be performed under HILO (Tokunaga et al., 2008), Epi and TIRF illumination (Hedde and Nienhaus, 2014), whereby TIRF will give the best signal, followed by HILO and last Epi. 3D-PALM features dependent on the 3D-technology used to capture ranges between 1.2 and $2.0 \mu \mathrm{m}$. This range might be extended by using classical z-scans. For a better signal 
HILO instead of Epi illumination is recommended (van de Linde et al., 2011). TIRF and for best performance also HILO illumination need the positioning of the specimen very close to the coverslip surface. Thus, the preparation of specimens directly onto coverslips has to be performed. These coverslips may be fixed onto slides by rubber cement and then be handled as usual during the staining and washing procedures. After placing them into coverslip chambers, adding a redox reagent and adjusting the $\mathrm{pH}$ to the needs of the dye to achieve efficient photoactivation, PALM can be performed (Weisshart et al., 2016). The redox reagent, e.g., 1\% 2-mercaptoethanol in 1x PBS can be used if the fluorescence dyes in the specimens are easily accessible. Otherwise, adding of glucose is required (Olivier et al., 2013; Schäfer et al., 2013).

PALM using fluorescent proteins can be performed in buffers like PBS or Hepes. Acquiring raw data sets takes $\sim 15 \mathrm{~min}$, followed by a calculation procedure of also $\sim 15 \mathrm{~min}$ if, e.g., isolated nuclei and the Elyra PS.1 is used.

Non-commercial super-resolution microscope setups (Hamel et al., 2014) and commercial systems as the Elyra PS.1 (Weisshart et al., 2016) allow producing SIM and PALM/STORM data subsequently. Thereby, the observed SIM structures can be combined with precise PALM/STORM single molecule localization and counting. This clearly increases the information obtained from the specimens under investigation (Figure 3).

\section{Life Cell Imaging}

Expressed fluorescent reporter proteins allow visualizing proteins and structures inside living organisms (Hedde and Nienhaus, 2014). Because the implementation of super-resolution microscopy in live cell microscopy is very challenging and both structured illumination and localization microscopy have different advantages and disadvantages (Schermelleh et al., 2010), to date only few publications describing the dynamics of plant cell components appeared (see above).

Propagating seedlings in coverslip chambers under sterile conditions allow live cell imaging by SIM on roots growing closely along the coverslip. However, due to the fast root elongation via cell extension the imaging time (e.g., in Arabidopsis) is limited, because the roots quickly leave (within $\sim 30 \mathrm{~min}$ ) the field of view.

The application of hypocotyls circumvents this problem. Samaj and co-workers produced excellent super-resolved movies via SIM by analyzing the microtubule development in Arabidopsis hypocotyl epidermal cells by adapting the settings accordingly to acquire the raw data. For tissue etiolation the seedlings were grown in darkness which induces the thinning of the outer epidermal wall and reduces the thickness of the cuticular surface. Then, after mounting the seedlings into aqueous growth medium, effects causing refractive index mismatches can be reduced (Komis et al., 2014, 2015a).

PALM in living cells was performed on Nicotiana BY-2 cell cultures after transferring the cells into coverslip chambers (Chamber Slides ${ }^{\mathrm{TM}}$, Thermo Scientific) to localize perinuclear actin (Durst et al., 2014).

Single particle tracking by PALM was used for the first time on living plants by Hosy et al. (2015). They mounted Arabidopsis seedlings between two coverslips to track plasma membrane proteins.

\section{CONCLUSION AND PERSPECTIVE}

Currently, most results obtained by super-resolution microscopy in plant cell research are concentrated in the fields of research groups with access to super-resolution microscopes. But it is expected that the applications will extent in future significantly due to the general applicability of super-resolution to analyze biological specimens, so that super-resolution microscopy will become a standard technique also in plant cell research.

This development will be further accelerated by improving and combining the existing super-resolution methods. Especially SIM has the potential for extended applications in the field of live cell imaging. Additionally, SIM methods are under development to excel its to date achieved two-fold increased resolution.

To image also thick fluorescent samples (Calliphora salivary glands) SIM was combined with line-scanning to remove disturbing out-of-focus fluorescence background deteriorating the illumination pattern (Mandula et al., 2012). Rego et al. (2012) developed nonlinear SIM, and thus were able to visualize with $\mathrm{a} \sim 40 \mathrm{~nm}$ resolution purified microtubules, mammalian nuclear pores and the actin cytoskeleton by applying the fluorescent photoswitchable protein Dronpa.

SIM can be applied for live cell imaging in multiple colors by using conventional fluorescent dyes as fast as 11 frames/s (Kner et al., 2009) at intensities of only 1 to $100 \mathrm{~W} / \mathrm{cm}^{2}$ preventing phototoxicity (Li et al., 2015). Betzig and co-workers extended the resolution of live cell SIM by using an ultrahigh numerical aperture TIRF-SIM and achieved up to $84 \mathrm{~nm}$, and by patterned nonlinear SIM they obtained up to $45-62 \mathrm{~nm}$. By this approach the dynamics of plasma membranes components, mitochondria, actin and the Golgi apparatus in cultured mammalian cells has been imaged ( $\mathrm{Li}$ et al., 2015). In addition, patterned nonlinear SIM and lattice light sheet microscopy (Chen et al., 2014) were combined to perform 3D live cell imaging beyond the diffraction limit (Li et al., 2015).

Gao et al. (2012) performed in vivo karyotyping of somatic chromosomes and identified the dynamics of the cytoskeleton of fibroblasts by combining an ultrathin planar illumination (produced by scanned Bessel beams) with SIM at thick animal specimens. Similarly, based on this technique the dynamics of mitochondria, filopodia, membrane ruffles, intracellular vesicles, and mitotic chromosomes in living cultured cells were investigated (Planchon et al., 2011).

It is expected that also the use of localization microscopy for absolute molecule quantification will be intensified in future, and that the combination with SIM will be increased to employ the advantages of these different nanoscopical methods. Standingwave microscopy has the potential for parallel super-resolution imaging as it simultaneously draws on SIM, PALM, and STED technologies Chen and Xi (2015).

Recently, methods were developed to expand biological specimens physically by synthesizing a swellable polymer network within the specimen. This process called expansion 
microscopy allows to separate labels spaced closer than the optical diffraction limit isotropically. Thus, super-resolution with diffraction-limited microscopes may be achieved (Chen et al., 2015, 2016; Engerer et al., 2016). However, it remains to be tested whether the swelling process is applicable to all organisms and tissues, amongst others those from plants, without disturbing the native structures. Additionally, the technique is not applicable for live cell imaging. Thus, it is not expected that expansion microscopy has the potential to replace optical nanoscopy. But both have the potential to be combined in some special applications.

Furthermore, with the development of genetically encoded markers for electron microscopy (Shu et al., 2011; Martell et al., 2012) correlative approaches with super-resolution techniques will become more powerful in near future. However, due to the harsher fixing conditions and the lack in high specificity electron

\section{REFERENCES}

Abbe, E. (1873). Beiträge zur Theorie des Mikroskops und der mikroskopischen Wahrnehmung. Arch. Mikrosk. Anat. 9, 413-468. doi: 10.1007/BF02956173

Agrawal, U., Reilly, D. T., and Schroeder, C. M. (2013). Zooming in on biological processes with fluorescence nanoscopy. Curr. Opin. Biotechnol. 24, 646-653. doi: 10.1016/j.copbio.2013.02.016

Allen, J. R., Ross, S. T., and Davidson, M. W. (2014). Structured illumination microscopy for superresolution. Chemphyschem 15, 566-576. doi: 10.1002/ cphc. 201301086

Antosch, M., Schubert, V., Holzinger, P., Houben, A., and Grasser, K. D. (2015). Mitotic lifecycle of chromosomal 3xHMG-box proteins and the role of their $\mathrm{N}$-terminal domain in the association with rDNA loci and proteolysis. New Phytol. 208, 1067-1077. doi: 10.1111/nph.13575

Antosz, W., Pfab, A., Ehrnsberger, H. F., Holzinger, H., Köllen, K., Mortensen, S. A., et al. (2017). The composition of the Arabidopsis RNA polymerase II transcript elongation complex reveals the interplay between elongation and mRNA processing factors. Plant Cell. doi: 10.1105/tpc.16.00735 [Epub ahead of print].

Banaei-Moghaddam, A. M., Schubert, V., Kumke, K., Weibeta, O., Klemme, S., Nagaki, K., et al. (2012). Nondisjunction in favor of a chromosome: the mechanism of rye B chromosome drive during pollen mitosis. Plant Cell 24, 4124-4134. doi: 10.1105/tpc.112.105270

Batzenschlager, M., Lermontova, I., Schubert, V., Fuchs, J., Berr, A., Koini, M. A., et al. (2015). Arabidopsis MZT1 homologs GIP1 and GIP2 are essential for centromere architecture. Proc. Natl. Acad. Sci. U.S.A. 112, 8656-8660. doi: 10.1073/pnas.1506351112

Bell, K., Mitchell, S., Paultre, D., Posch, M., and Oparka, K. (2013). Correlative imaging of fluorescent proteins in resin-embedded plant material. Plant Physiol. 161, 1595-1603. doi: 10.1104/pp.112.212365

Bell, K., and Oparka, K. (2011). Imaging plasmodesmata. Protoplasma 248, 9-25. doi: 10.1007/s00709-010-0233-6

Bell, K., and Oparka, K. (2015). Preparative methods for imaging plasmodesmata at super-resolution. Methods Mol. Biol. 1217, 67-79. doi: 10.1007/978-1-49391523-1_4

Bozkurt, T. O., Richardson, A., Dagdas, Y. F., Mongrand, S., Kamoun, S., and Raffaele, S. (2014). The plant membrane-associated REMORIN1.3 accumulates in discrete perihaustorial domains and enhances susceptibility to Phytophthora infestans. Plant Physiol. 165, 1005-1018. doi: 10.1104/pp.114.235804

Cabral, G., Marques, A., Schubert, V., Pedrosa-Harand, A., and Schlögelhofer, P. (2014). Chiasmatic and achiasmatic inverted meiosis of plants with holocentric chromosomes. Nat. Commun. 5:5070. doi: 10.1038/ncomms6070

Chen, B. C., Legant, W. R., Wang, K., Shao, L., Milkie, D. E., Davidson, M. W., et al. (2014). Lattice light-sheet microscopy: imaging molecules to embryos at high spatiotemporal resolution. Science 346:1257998. doi: 10.1126/science.1257998

Chen, F., Tillberg, P. W., and Boyden, E. S. (2015). Optical imaging. Expansion microscopy. Science 347, 543-548. doi: 10.1126/science. 1260088 microscopy will not have the potential to replace completely the super-resolution techniques as live cell imaging is not possible and multi-color labeling is a challenge.

\section{AUTHOR CONTRIBUTIONS}

VS conceived and designed the study, performed the experiments and wrote the manuscript.

\section{ACKNOWLEDGMENT}

I thank Jörg Fuchs for flow sorting of nuclei, Martina Kühne and Andrea Kunze for slide preparation, Andreas Houben and Klaus Weisshart for critical reading of the manuscript.

Chen, F., Wassie, A. T., Cote, A. J., Sinha, A., Alon, S., Asano, S., et al. (2016). Nanoscale imaging of RNA with expansion microscopy. Nat. Methods 13, 679-684. doi: 10.1038/nmeth.3899

Chen, X., and Xi, P. (2015). Hundred-thousand light holes push nanoscopy to go parallel. Microsc. Res. Tech. 78, 8-10. doi: 10.1002/jemt. 22434

Cuacos, M. (2013). Analysis of a Secondary Constriction in Chromosome 5R of Rye and Its Neocentromeric Activity. Doctoral thesis, Facultad de Biologia Departamento de Genetica Universidad Complutense de Madrid, Madrid, 98.

Demidov, D., Schubert, V., Kumke, K., Weiss, O., Karimi-Ashtiyani, R., Buttlar, J., et al. (2014). Anti-phosphorylated histone H2AThr120: a universal microscopic marker for centromeric chromatin of mono- and holocentric plant species. Cytogenet. Genome Res. 143, 150-156. doi: 10.1159/00036 0018

Dong, B., Yang, X., Zhu, S., Bassham, D. C., and Fang, N. (2015). Stochastic optical reconstruction microscopy imaging of microtubule arrays in intact Arabidopsis thaliana seedling roots. Sci. Rep. 5:15694. doi: 10.1038/srep 15694

Dürr, J., Lolas, I. B., Sorensen, B. B., Schubert, V., Houben, A., Melzer, M., et al. (2014). The transcript elongation factor SPT4/SPT5 is involved in auxin-related gene expression in Arabidopsis. Nucleic Acids Res. 42, 4332-4347. doi: 10.1093/ nar/gku096

Durst, S., Hedde, P. N., Brochhausen, L., Nick, P., Nienhaus, G. U., and Maisch, J. (2014). Organization of perinuclear actin in live tobacco cells observed by PALM with optical sectioning. J. Plant Physiol. 171, 97-108. doi: 10.1016/j.jplph. 2013.10.007

Dvořáčková, M., Raposo, B., Matula, P., Fuchs, J., Schubert, V., Peška, V., et al. (in press). Replication of ribosomal DNA in Arabidopsis occurs both inside and outside of the nucleolus during S-phase progression. J. Cell Sci. doi: 10.1242/jcs. 202416

Engerer, P., Fecher, C., and Misgeld, T. (2016). Super-resolution microscopy writ large. Nat. Biotechnol. 34, 928-930. doi: 10.1038/nbt.3669

Fernández-Suárez, M., and Ting, A. Y. (2008). Fluorescent probes for superresolution imaging in living cells. Nat. Rev. Mol. Cell Biol. 9, 929-943. doi: 10.1038/nrm2531

Fitzgibbon, J., Beck, M., Zhou, J., Faulkner, C., Robatzek, S., and Oparka, K. (2013). A developmental framework for complex plasmodesmata formation revealed by large-scale imaging of the Arabidopsis leaf epidermis. Plant Cell 25, 57-70. doi: $10.1105 /$ tpc. 112.105890

Fitzgibbon, J., Bell, K., King, E., and Oparka, K. (2010). Super-resolution imaging of plasmodesmata using three-dimensional structured illumination microscopy. Plant Physiol. 153, 1453-1463. doi: 10.1104/pp.110.157941

Fornasiero, E. F., and Opazo, F. (2015). Super-resolution imaging for cell biologists: concepts, applications, current challenges and developments. Bioessays 37, 436-451. doi: 10.1002/bies.201400170

Gao, L., Shao, L., Higgins, C. D., Poulton, J. S., Peifer, M., Davidson, M. W., et al. (2012). Noninvasive imaging beyond the diffraction limit of 3D dynamics 
in thickly fluorescent specimens. Cell 151, 1370-1385. doi: 10.1016/j.cell.2012. 10.008

Gevaux, D. (2014). Nobel prize in chemistry: seeing the nanoscale. Nat. Nanotechnol. 9, 878. doi: 10.1038/nnano.2014.267

Gustafsson, M. G. (2005). Nonlinear structured-illumination microscopy: widefield fluorescence imaging with theoretically unlimited resolution. Proc. Natl. Acad. Sci. U.S.A. 102, 13081-13086. doi: 10.1073/pnas.0406877102

Gustafsson, M. G., Shao, L., Carlton, P. M., Wang, C. J., Golubovskaya, I. N., Cande, W. Z., et al. (2008). Three-dimensional resolution doubling in wide-field fluorescence microscopy by structured illumination. Biophys. J. 94, 4957-4970. doi: 10.1529/biophysj.107.120345

Hamel, V., Guichard, P., Fournier, M., Guiet, R., Fluckiger, I., Seitz, A., et al. (2014). Correlative multicolor 3D SIM and STORM microscopy. Biomed. Opt. Express 5, 3326-3336. doi: 10.1364/BOE.5.003326

Han, R., Li, Z., Fan, Y., and Jiang, Y. (2013). Recent advances in super-resolution fluorescence imaging and its applications in biology. J. Genet. Genomics 40, 583-595. doi: 10.1016/j.jgg.2013.11.003

Heckmann, S., Jankowska, M., Schubert, V., Kumke, K., Ma, W., and Houben, A. (2014). Alternative meiotic chromatid segregation in the holocentric plant Luzula elegans. Nat. Commun. 5:4979. doi: 10.1038/ncomms5979

Heckmann, S., Macas, J., Kumke, K., Fuchs, J., Schubert, V., Ma, L., et al. (2013). The holocentric species Luzula elegans shows interplay between centromere and large-scale genome organization. Plant J. 73, 555-565. doi: 10.1111/tpj. 12054

Hedde, P. N., and Nienhaus, G. U. (2014). Super-resolution localization microscopy with photoactivatable fluorescent marker proteins. Protoplasma 251, 349-362. doi: 10.1007/s00709-013-0566-z

Hosy, E., Martiniere, A., Choquet, D., Maurel, C., and Luu, D. T. (2015). Superresolved and dynamic imaging of membrane proteins in plant cells reveal contrasting kinetic profiles and multiple confinement mechanisms. Mol. Plant 8, 339-342. doi: 10.1016/j.molp.2014.10.006

Ishii, T., Karimi-Ashtiyani, R., Banaei-Moghaddam, A. M., Schubert, V., Fuchs, J., and Houben, A. (2015). The differential loading of two barley CENH3 variants into distinct centromeric substructures is cell type- and development-specific. Chromosome Res. 23, 277-284. doi: 10.1007/s10577-015-9466-8

Jankowska, M., Fuchs, J., Klocke, E., Fojtova, M., Polanska, P., Fajkus, J., et al. (2015). Holokinetic centromeres and efficient telomere healing enable rapid karyotype evolution. Chromosoma 124, 519-528. doi: 10.1007/s00412-0150524-y

Karimi-Ashtiyani, R., Ishii, T., Niessen, M., Stein, N., Heckmann, S., Gurushidze, M., et al. (2015). Point mutation impairs centromeric CENH3 loading and induces haploid plants. Proc. Natl. Acad. Sci. U.S.A. 112, 11211-11216. doi: 10.1073/pnas.1504333112

Kleine-Vehn, J., Wabnik, K., Martiniere, A., Langowski, L., Willig, K., Naramoto, S., et al. (2011). Recycling, clustering, and endocytosis jointly maintain PIN auxin carrier polarity at the plasma membrane. Mol. Syst. Biol. 7, 540. doi: 10.1038/ $\mathrm{msb} .2011 .72$

Klemme, S. (2013). High Copy Sequences Reveal the Unique Composition and Evolution of the Rye B Chromosome. Doctoral thesis, Martin-Luther-University Halle-Wittenberg, Halle, 95.

Kner, P., Chhun, B. B., Griffis, E. R., Winoto, L., and Gustafsson, M. G. (2009). Super-resolution video microscopy of live cells by structured illumination. Nat. Methods 6, 339-342. doi: 10.1038/nmeth.1324

Knox, K., Wang, P. W., Kriechbaumer, V., Tilsner, J., Frigerio, L., Sparkes, I., et al. (2015). Putting the squeeze on plasmodesmata: a role for reticulons in primary plasmodesmata formation. Plant Physiol. 168, 1563-1572. doi: 10.1104/pp.15. 00668

Komis, G., Mistrik, M., Samajova, O., Doskocilova, A., Ovecka, M., Illes, P., et al. (2014). Dynamics and organization of cortical microtubules as revealed by superresolution structured illumination microscopy. Plant Physiol. 165, 129-148. doi: 10.1104/pp.114.238477

Komis, G., Mistrik, M., Samajova, O., Ovecka, M., Bartek, J., and Samaj, J. (2015a). Superresolution live imaging of plant cells using structured illumination microscopy. Nat. Protocols 10, 1248-1263. doi: 10.1038/nprot. 2015.083

Komis, G., Samajova, O., Ovecka, M., and Samaj, J. (2015b). Super-resolution microscopy in plant cell imaging. Trends Plant Sci. 20, 834-843. doi: 10.1016/j. tplants.2015.08.013
Lermontova, I., Kuhlmann, M., Friedel, S., Rutten, T., Heckmann, S., Sandmann, M., et al. (2013). Arabidopsis kinetochore null2 is an upstream component for centromeric histone $\mathrm{H} 3$ variant cenH3 deposition at centromeres. Plant Cell 25, 3389-3404. doi: 10.1105/tpc.113.114736

Li, D., Shao, L., Chen, B. C., Zhang, X., Zhang, M., Moses, B., et al. (2015). Extended-resolution structured illumination imaging of endocytic and cytoskeletal dynamics. Science 349, aab3500. doi: 10.1126/science.aab3500

Liesche, J., Ziomkiewicz, I., and Schulz, A. (2013). Super-resolution imaging with Pontamine Fast Scarlet 4BS enables direct visualization of cellulose orientation and cell connection architecture in onion epidermis cells. BMC Plant Biol. 13:226. doi: 10.1186/1471-2229-13-226

Linnik, O., Liesche, J., Tilsner, J., and Oparka, K. J. (2013). Unraveling the structure of viral replication complexes at super-resolution. Front. Plant Sci. 4:6. doi: $10.3389 /$ fpls.2013.00006

Ma, W., Gabriel, T. S., Martis, M. M., Gursinsky, T., Schubert, V., Vrana, J., et al. (2017). Rye B chromosomes encode a functional Argonaute-like protein with in vitro slicer activities similar to its A chromosome paralog. New Phytol. 213, 916-928. doi: 10.1111/nph.14110

Ma, W., Schubert, V., Martis, M. M., Hause, G., Liu, Z., Shen, Y., et al. (2016). The distribution of alpha-kleisin during meiosis in the holocentromeric plant Luzula elegans. Chromosome Res. 24, 393-405. doi: 10.1007/s10577-0169529-5

Maheshwari, S., Ishii, T., Brown, C. T., Houben, A., and Comai, L. (2016). Centromere location in Arabidopsis is unaltered by drastic divergence in CENH3 protein sequence. Genome Res. 27, 471-478. doi: 10.1101/gr. 214619.116

Mandula, O., Kielhorn, M., Wicker, K., Krampert, G., Kleppe, I., and Heintzmann, R. (2012). Line scan-structured illumination microscopy superresolution imaging in thick fluorescent samples. Opt. Express 20, 24167-24174. doi: 10.1364/OE.20.024167

Marques, A., Ribeiro, T., Neumann, P., Macas, J., Novak, P., Schubert, V., et al. (2015). Holocentromeres in Rhynchospora are associated with genome-wide centromere-specific repeat arrays interspersed among euchromatin. Proc. Natl. Acad. Sci. U.S.A. 112, 13633-13638. doi: 10.1073/pnas.1512255112

Marques, A., Schubert, V., Houben, A., and Pedrosa-Harand, A. (2016). Restructuring of holocentric centromeres during meiosis in the plant Rhynchospora pubera. Genetics 204, 555-568. doi: 10.1534/genetics.116.191213

Martell, J. D., Deerinck, T. J., Sancak, Y., Poulos, T. L., Mootha, V. K., Sosinsky, G. E., et al. (2012). Engineered ascorbate peroxidase as a genetically encoded reporter for electron microscopy. Nat. Biotechnol. 30, 1143-1148. doi: 10.1038/ nbt. 2375

Möckl, L., Lamb, D. C., and Bräuchle, C. (2014). Super-resolved fluorescence microscopy: nobel Prize in Chemistry 2014 for Eric Betzig, Stefan Hell, and William E. Moerner. Angew. Chem. Int. Ed. Engl. 53, 13972-13977. doi: 10.1002/ anie. 201410265

Neumann, P., Schubert, V., Fukova, I., Manning, J. E., Houben, A., and Macas, J. (2016). Epigenetic histone marks of extended meta-polycentric centromeres of Lathyrus and Pisum chromosomes. Front. Plant Sci. 7:234. doi: 10.3389/fpls. 2016.00234

Nienhaus, K., and Nienhaus, G. U. (2016). Where do we stand with superresolution optical microscopy? J. Mol. Biol. 428, 308-322. doi: 10.1016/j.jmb. 2015.12.020

Olivier, N., Keller, D., Rajan, V. S., Gonczy, P., and Manley, S. (2013). Simple buffers for 3D STORM microscopy. Biomed. Opt. Express 4, 885-899. doi: 10.1364/BOE.4.000885

Pawley, J. B. (1995). Handbook of Biological Confocal Microscopy. New York, NY: Plenum Press.

Phillips, D., Nibau, C., Wnetrzak, J., and Jenkins, G. (2012). High resolution analysis of meiotic chromosome structure and behaviour in barley (Hordeum vulgare L.). PLoS ONE 7:e39539. doi: 10.1371/journal.pone.0039539

Planchon, T. A., Gao, L., Milkie, D. E., Davidson, M. W., Galbraith, J. A., Galbraith, C. G., et al. (2011). Rapid three-dimensional isotropic imaging of living cells using Bessel beam plane illumination. Nat. Methods 8, 417-423. doi: 10.1038/ nmeth.1586

Rego, E. H., Shao, L., Macklin, J. J., Winoto, L., Johansson, G. A., KampsHughes, N., et al. (2012). Nonlinear structured-illumination microscopy with a photoswitchable protein reveals cellular structures at 50-nm resolution. Proc. Natl. Acad. Sci. U.S.A. 109, E135-E143. doi: 10.1073/pnas.1107547108 
Ribeiro, T., Marques, A., Novák, P., Schubert, V., Vanzela, A. L. L., Macas, J., et al. (2017). Centromeric and non-centromeric satellite DNA organisation differs in holocentric Rhynchospora species. Chromosoma 126, 325-335. doi: 10.1007/s00412-016-0616-3

Rouquette, J., Cremer, C., Cremer, T., and Fakan, S. (2010). Functional nuclear architecture studied by microscopy: present and future. Intern. Rev. Cell Mol. Biol. 282, 1-90. doi: 10.1016/S1937-6448(10)82001-5

Ruban, A., Fuchs, J., Marques, A., Schubert, V., Soloviev, A., Raskina, O., et al. (2014). B chromosomes of Aegilops speltoides are enriched in organelle genome-derived sequences. PLOS ONE 9:e90214. doi: 10.1371/journal.pone. 0090214

Sandmann, M., Talbert, P., Demidov, D., Kuhlmann, M., Rutten, T., Conrad, U., et al. (2017). Targeting of A. thaliana KNL2 to centromeres depends on the conserved CENPC-k motif in its C-terminus. Plant Cell 29, 144-155. doi: 10.1105/tpc.16.00720

Schäfer, P., van de Linde, S., Lehmann, J., Sauer, M., and Doose, S. (2013). Methylene blue- and thiol-based oxygen depletion for super-resolution imaging. Anal. Chem. 85, 3393-3400. doi: 10.1021/ac400035k

Schermelleh, L., Heintzmann, R., and Leonhardt, H. (2010). A guide to superresolution fluorescence microscopy. J. Cell Biol. 190, 165-175. doi: 10.1083/jcb. 201002018

Schubert, V. (2014). RNA polymerase II forms transcription networks in rye and Arabidopsis nuclei and its amount increases with endopolyploidy. Cytogenet. Genome Res. 143, 69-77. doi: 10.1159/000365233

Schubert, V., Lermontova, I., and Schubert, I. (2013). The Arabidopsis CAP-D proteins are required for correct chromatin organisation, growth and fertility. Chromosoma 122, 517-533. doi: 10.1007/s00412-013-0424-y

Schubert, V., Lermontova, I., and Schubert, I. (2014). Loading of the centromeric histone H3 variant during meiosis - how does it differ from mitosis? Chromosoma 123, 491-497. doi: 10.1007/s00412-014-0466-9

Schubert, V., Ruban, A., and Houben, A. (2016a). Chromatin ring formation at plant centromeres. Front. Plant Sci. 7:28. doi: 10.3389/fpls.2016.00028

Schubert, V., Zelkowski, M., Klemme, S., and Houben, A. (2016b). Similar sister chromatid arrangement in mono- and holocentric plant chromosomes. Cytogenet. Genome Res. 149, 218-225. doi: 10.1159/000447681

Schubert, V., and Weisshart, K. (2015). Abundance and distribution of RNA polymerase II in Arabidopsis interphase nuclei. J. Exp. Bot. 66, 1687-1698. doi: 10.1093/jxb/erv091

Shu, X. K., Lev-Ram, V., Deerinck, T. J., Qi, Y. C., Ramko, E. B., Davidson, M. W., et al. (2011). A genetically encoded tag for correlated light and electron microscopy of intact cells, tissues, and organisms. PLoS Biol. 9:e1001041. doi: 10.1371/journal.pbio.1001041

Sivaguru, M., Mander, L., Fried, G., and Punyasena, S. W. (2012). Capturing the surface texture and shape of pollen: a comparison of microscopy techniques. PLoS ONE 7:e39129. doi: 10.1371/journal.pone.0039129

Sousa, A., Bellot, S., Fuchs, J., Houben, A., and Renner, S. (2016). Analysis of transposable elements and organellar DNA in male and female genomes of a species with a huge Y-chromosome reveals distinct Y-centromeres. Plant J. 88, 387-396. doi: 10.1111/tpj.13254

Staudt, T., Lang, M. C., Medda, R., Engelhardt, J., and Hell, S. W. (2007). 2,2'thiodiethanol: a new water soluble mounting medium for high resolution optical microscopy. Microsc. Res. Tech. 70, 1-9. doi: 10.1002/jemt.20396
Stelzer, E. H. (2014). Better imaging through chemistry. Cell 159, 1243-1246. doi: 10.1016/j.cell.2014.11.032

Tilsner, J., Linnik, O., Louveaux, M., Roberts, I. M., Chapman, S. N., and Oparka, K. J. (2013). Replication and trafficking of a plant virus are coupled at the entrances of plasmodesmata. J. Cell Biol. 201, 981-995. doi: 10.1083/jcb. 201304003

Tokunaga, M., Imamoto, N., and Sakata-Sogawa, K. (2008). Highly inclined thin illumination enables clear single-molecule imaging in cells. Nat. Methods 5, 159-161. doi: 10.1038/Nmeth.1171

van de Linde, S., Löschberger, A., Klein, T., Heidbreder, M., Wolter, S., Heilemann, M., et al. (2011). Direct stochastic optical reconstruction microscopy with standard fluorescent probes. Nat. Protoc. 6, 991-1009. doi: 10.1038/nprot.2011.336

von Wangenheim, D., Rosero, A., Komis, G., Samajova, O., Ovecka, M., Voigt, B., et al. (2016). Endosomal interactions during root hair growth. Front. Plant Sci. 6:1262. doi: 10.3389/fpls.2016.00028

Vu, G. T., Cao, H. X., Watanabe, K., Hensel, G., Blattner, F. R., Kumlehn, J., et al. (2014). Repair of site-specific DNA double-strand breaks in barley occurs via diverse pathways primarily involving the sister chromatid. Plant Cell 26, 2156-2167. doi: 10.1105/tpc.114.126607

Wang, C. J., Carlton, P. M., Golubovskaya, I. N., and Cande, W. Z. (2009). Interlock formation and coiling of meiotic chromosome axes during synapsis. Genetics 183, 905-915. doi: 10.1534/genetics.109.108688

Wanner, G., Schroeder-Reiter, E., Ma, W., Houben, A., and Schubert, V. (2015). The ultrastructure of mono- and holocentric plant centromeres: an immunological investigation by structured illumination microscopy and scanning electron microscopy. Chromosoma 124, 503-517. doi: 10.1007/ s00412-015-0521-1

Weisshart, K., Fuchs, J., and Schubert, V. (2016). Structured illumination microscopy (SIM) and photoactivated localization microscopy (PALM) to analyze the abundance and distribution of RNA polymerase II molecules in flow-sorted Arabidopsis nuclei. Bio Protocol. 6, e1725. doi: 10.21769/BioProtoc. 1725

Zakrzewski, F., Schubert, V., Viehoever, P., Minoche, A. E., Dohm, J. C., Himmelbauer, H., et al. (2014). The $\mathrm{CHH}$ motif in sugar beet satellite DNA: a modulator for cytosine methylation. Plant J. 78, 937-950. doi: 10.1111/tpj. 12519

Conflict of Interest Statement: The author declares that the research was conducted in the absence of any commercial or financial relationships that could be construed as a potential conflict of interest.

The reviewer FH and handling Editor declared their shared affiliation, and the handling Editor states that the process nevertheless met the standards of a fair and objective review.

Copyright (C) 2017 Schubert. This is an open-access article distributed under the terms of the Creative Commons Attribution License (CC BY). The use, distribution or reproduction in other forums is permitted, provided the original author(s) or licensor are credited and that the original publication in this journal is cited, in accordance with accepted academic practice. No use, distribution or reproduction is permitted which does not comply with these terms. 